\title{
РОЗВИТОК ОБЛІКУ ЗА ЦЕНТРАМИ ВІДПОВІДАЛЬНОСТІ В СИСТЕМІ УПРАВЛІННЯ ПІДПРИЄМСТВОМ
}

\section{DEVELOPMENT OF ACCOUNTING BY RESPONSIBILITY CENTERS IN THE ENTERPRISE MANAGEMENT SYSTEM}

\author{
Мірошниченко Олеся Володимирівна \\ кандидат економічних наук, старший викладач, \\ Сумський державний університет \\ ORCID: https://orcid.org/0000-0002-7213-4601
Винниченко Наталія Володимирівна
доктор економічних наук, доцент,
Сумський державний університет \\ ORCID: https://orcid.org/0000-0002-6730-4629
Андрєєва Наталія Леонідівна
студентка, \\ Сумський державний університет \\ ORCID: https://orcid.org/0000-0002-1471-5053
}

\author{
Miroshnychenko Olesia, Vynnychenko Nataliia, Andreeva Nataliia \\ Sumy State University
}

\begin{abstract}
Стаття присвячена актуальним питанням організації обліку за центрами відповідальності в системі управління підприємством. Проаналізовано та систематизовано підходи до визначення поняття «центр відповідальності». Досліджено підходи до визначення поняття «облік за центрами відповідальності». Аналіз широкого кола наукових джерел показав, що існує багато критеріїв, за якими класифрікуються центри відповідальності. У статті наведено порівняльну характеристику центрів відповідальності затрат, доходів, прибутку та інвестицій за такими параметрами, як: завдання управлінського обліку, критерії оцінки діяльності центру, фрінансова відповідальність, повноваження керівників Досліджено критерії виділення центрів відповідальності. Окреслено перспективи подальшого розвитку обліку за центрами відповідальності.
\end{abstract}

Ключові слова: управлінський облік, центр відповідальності, облік за центрами відповідальності.

Статья посвящена актуальным вопросам организации учета по центрам ответственности в системе управления предприятием. Проанализированы и систематизированы подходы к определению понятия «центр ответственности». Исследуются подходы к определению понятия «учет по центрам ответственности». Анализ широкого круга научных источников показал, что существует много критериев, по которым классифицируются центры ответственности. В статье приведена сравнительная характеристика центров ответственности затрат, доходов, прибыли и инвестиций по таким параметрам, как: задачи управленческого учета, критерии оценки деятельности центра, фринансовая ответственность, полномочия руководителей. Исследованы критерии выделения центров ответственности. Определены перспективы дальнейшего развития учета по центрам ответственности.

Ключевые слова: управленческий учет, центр ответственности, учет по центрам ответственности.

For a long time in Ukraine, accounting at enterprises was based on the need and obligation of the state. This has led to a pronounced tax nature of accounting and reporting. During the thirty years of forming market relations in our country, this problem has become acute in enterprises seeking to take a leading position in the market. Senior managers faced the problem of a lack of information to make strategically important management decisions. Therefore, management accounting for the centers of responsibility in large and medium-sized and even small domestic enterprises has become necessary. The article is devoted to topical issues of organization of accounting by centres of responsibility in the enterprise management system. Approaches to the definition of the concept of "centre of responsibility" are analyzed and systematized. Based on the analysis results, a clarifying definition of the term "responsibility centre" is proposed. Approaches to the definition of the concept of "accounting by centres of responsibility" are studied. Although in the construction of the enterprise accounting for the centers of responsibility must take into 
account the individual characteristics of the enterprise general requirements for the organization of the accounting system for the centers of responsibility were identified. The organization of accounting by centres of responsibility is impossible without allocating certain types of responsibility centres. Analysis of a wide range of scientific sources has shown that there are many criteria according to which centres of responsibility are classified. The article provides a comparative description of the centres of responsibility for costs, revenues, profits and investments in such parameters as: management accounting tasks, criteria for evaluating the centre's activities, financial responsibility, powers of managers. Other criteria for selecting centres of responsibility, which researchers identify, have been studied. Prospects for further development of accounting by centres of responsibility are outlined.

Keywords: management accounting, centre of responsibility, responsibility accounting.

Постановка проблеми. Глобальні зміни в економічному середовищі, що відбуваються останнім часом, вимагають нового погляду на ефрективність діяльності підприємств та організацій, а також їх структурних підрозділів. Керівники, зосередивши повноваження щодо прийняття рішень в своїх руках, втрачають можливість глибокого і всебічного вивчення та аналізу не тільки поточних, а й стратегічних цілей, що $€$ неприйнятним в сучасних умовах їх фрункціонування. Вирішити цю проблему дозволяє делегування повноважень щодо прийняття деяких рішень керівникам середньої ланки. Це дає можливість підвищити якість управління як організацією в цілому, так і за напрямками виробничо-господарської діяльності, а так само ефективність управління підрозділами на основі узагальнення даних про доходи, витрати і результати діяльності 3 тим, щоб виникаючі відхилення можна було легко контролювати та відносити на конкретного керівника. Забезпечити подібний чіткий зв'язок між результатами діяльності і відповідальністю керівників підрозділів, які звітують за результати своєї роботи перед вищим керівництвом, можлива за допомогою виділення в організації так званих центрів відповідальності.

Аналіз останніх досліджень і публікацій. Дослідженню питань організації обліку за центрами відповідальності присвячені праці багатьох зарубіжних та вітчизняних економістів: Ф.Ф. Бутинець [1], В.С. Лень [2], О.М. Миронюк [3], П.Н. Атамас [4] та інші.

Виділення невирішених раніше частин загальної проблеми. Довгий час в Україні ведення бухгалтерського обліку на підприємствах ґрунтувалося на необхідності та обов'язковості з боку держави. Перш за все це призвело до яскраво вираженого податковому характеру обліку та звітності. За тридцятирічний період фрормування ринкових відносин в нашій країні ця проблема гостро стала відчуватися на підприємствах, котрі прагнуть займати лідерські позиції на ринку. Менеджери вищого рівня управління зіткну- лися 3 проблемою браку інфрормації для прийняття стратегічно важливих управлінських рішень. А для висококонкурентного сучасного бізнес-середовища будь-яка помилка, навіть не на найвищому рівні управління, може бути надзвичайно небезпечною для бізнесу. Тому управлінський облік за центрами відповідальності на великих і середніх, та навіть на малих вітчизняних підприємствах став швидше необхідністю, оскільки на базі його звітності формуються основні стратегічні перспективи та приймаються найважливіші для майбутнього розвитку підприємства рішення.

Формулювання цілей статті. Метою статті $€$ дослідження теоретичних засад розвитку обліку за центрами відповідальності в системі управління підприємством.

Виклад основного матеріалу дослідження. В найбільш загальному розумінні центр відповідальності представляє собою структурний підрозділ в середині організації, що здійснює певний набір господарських операцій, очолюється конкретною особою, що приймає управлінські рішення та несе за них відповідальність. В Україні ідея управлінського обліку за центрами відповідальності отримала свій розвиток як відповідь на потребу покращення внутрішньофрірмового управління.

Ключовим терміном в концепції управлінського обліку за центрами відповідальності $€$ поняття «центр відповідальності». Тому 3 метою ґрунтовного розгляду сутності управлінського обліку за центрами відповідальності проведемо критичний аналіз підходів різних вчених до цього поняття (табл. 1), виділимо спільні та відмінні ознаки, а також на основі аналізу запропонуємо власне уточнене визначення економічної категорії «центр відповідальності».

Таким чином, розглянувши підходи різних науковців щодо визначення сутності поняття «центр відповідальності», можна виділити схожі ознаки:

- центр відповідальності $€$ відокремленим структурним підрозділом підприємства; 
Таблиця 1

Підходи до визначення поняття «центр відповідальності»

\begin{tabular}{|c|c|}
\hline Автор / джерело & Визначення \\
\hline $\begin{array}{l}\text { П.І. Атамас } \\
{[4, \text { с. } 124]}\end{array}$ & $\begin{array}{l}\text { Підрозділ, який очолює керівник, що несе особисту відповідальність } \\
\text { за результати його роботи }\end{array}$ \\
\hline $\begin{array}{l}\text { Ф.Ф. Бутинець } \\
{[1, \text { с. 42] }}\end{array}$ & $\begin{array}{l}\text { Сегмент діяльності підприємства, в якому встановлено персональну } \\
\text { відповідальність керівника за показники діяльності, які він повинен } \\
\text { контролювати }\end{array}$ \\
\hline $\begin{array}{l}\text { В. Добровольський } \\
{[5, \text { с. 89] }}\end{array}$ & $\begin{array}{l}\text { Структурний підрозділ, що здійснює певний набір господарських } \\
\text { операцій, який здатний здійснювати безпосередній вплив на витрати або } \\
\text { доходи від цих операцій і відповідає за величину цих витрат або доходів }\end{array}$ \\
\hline $\begin{array}{l}\text { Х.Л. Дюкарєва } \\
\text { [6, с. 159-168] }\end{array}$ & $\begin{array}{l}\text { Організаційна одиниця системи управління, керівник якої наділений } \\
\text { певними повноваженнями, делегованими йому вищим керівництвом, } \\
\text { та відповідальний за досягнення планових контрольних показників } \\
\text { та використання ресурсів якими розпоряджається (матеріальними, } \\
\text { трудовими, фрінансовими) }\end{array}$ \\
\hline $\begin{array}{l}\text { І.Г. Жукова } \\
{[7, \text { с. 393-398] }}\end{array}$ & $\begin{array}{l}\text { Частина організації, по якій доцільно акумулювати облікову інсормацію } \\
\text { про діяльність такого центру. Звіти центрів відповідальності повинні } \\
\text { включати статті доходів і витрат, на які може вплинути менеджер центру }\end{array}$ \\
\hline $\begin{array}{l}\text { В.С. Лень } \\
{[2, \text { с. } 121]}\end{array}$ & $\begin{array}{l}\text { Будь-який підрозділ підп } \\
\text { одержання доходів і яки }\end{array}$ \\
\hline $\begin{array}{l}\text { І.М. Лепетан } \\
{[8, \text { с. 19-24] }}\end{array}$ & $\begin{array}{l}\text { ний підрозділ організації, на чолі якого стоїть керівник } \\
\text { ер), який контролює в певному для даного підрозділу ступені } \\
\text { доходи і кошти, що інвестуються в цей сегмент бізнесу }\end{array}$ \\
\hline $\begin{array}{l}\text { Р. Сидоренко } \\
{[9, \text { с. 326] }}\end{array}$ & $\begin{array}{l}\text { Групування витрат, котре дозволяє поєднати в одному процесі місця } \\
\text { виникнення витрат: виробництво, цех, ділянку, бригаду } \\
\text { з відповідальністю керуючих ними менеджерів }\end{array}$ \\
\hline $\begin{array}{l}\text { М. Скрипник } \\
{[10, \text { с. } 48]}\end{array}$ & $\begin{array}{l}\text { Місце, де виникають правові відношення між учасниками господарськи } \\
\text { процесів }\end{array}$ \\
\hline
\end{tabular}

- результати роботи центру відповідальності обов'язково вимірюються і контролюються керівником (менеджером) центру;

- керівник (менеджер) центру несе пряму відповідальність за результати діяльності ввіреного йому підрозділу.

За результатами аналізу пропонується наступне уточнююче визначення поняття: центр відповідальності - це частина організації, що найчастіше всього представлена відокремленим структурним підрозділом, який управляється менеджером, що відповідає за певний бізнеспроцес чи господарську діяльність підприємства, та генеровані цією діяльністю доходи, витрати, ресурси та фрінансові результати.

Як відзначає Ю.Ю. Миронова, облік за центрами відповідальності (від англ. responsibility accounting) $€$ не новою але досить цікавою та практичною концепцією. Варто погодитися 3 тим, що подібний підхід до формування управлінського обліку на основі центрів відповідальності $є$ актуальним для компаній, для яких контроль за доходами та витратами $€$ ключовою умовою виживання на ринку. При цьому для диверсисрікованих підприємств, що мають по декілька напрямів діяльності, облік по центрам відповідальності виступає обов'язковою умовою успішного функціонування на ринку [11, с. 174-178].

У табл. 2 представлено підходи до визначення сутності обліку за центрами відповідальності.

Ідеальної схеми організації обліку за центрами відповідальності, яка була б універсальною та підходила для всіх без винятку підприємств, не існує, так як всі компанії різні, і відповідальність за господарські операції також делегується по-різному. Унікальна організаційна структура, специфрічний набір статей звітності, стиль керівництва в управлінні компанією та особливості взаємодії відділів створюють значні труднощі та вимагають індивідуального підходу до побудови управлінського обліку за центрами відповідальності.

Однак незважаючи на те, що при побудові на підприємстві обліку за центрами відповідальності потрібно враховувати індивідуальні особливості підприємства (структуру, технології, способи організації виробництва, рівень технічного оснащення, кадровий потенціал), все одно можна виділити деякі загальні вимоги до організації подібної системи обліку:

- при розподілі підприємства на центри відповідальності враховується структура компанії, як організаційна, так і виробнича; 
Таблиця 2

Підходи до визначення поняття «облік за центрами відповідальності»

\begin{tabular}{|c|c|}
\hline Автор / джерело & Визначення \\
\hline $\begin{array}{l}\text { О.М. Миронюк } \\
{[3]}\end{array}$ & $\begin{array}{l}\text { Система обліку, яка вимірює, оцінює відповідність досягнутих результатів } \\
\text { запланованим по кожному підрозділу (центру відповідальності), який є } \\
\text { самостійним об'єктом бюджетного (планового) процесу і відповідає за } \\
\text { виконання переліку бюджетних показників, закріплених за ним при розробці } \\
\text { зведеного бюджету підприємства на майбутній бюджетний період. } \\
\end{array}$ \\
\hline $\begin{array}{l}\text { олікарпова } \\
\text { 97-100] }\end{array}$ & $\begin{array}{l}\text { Система обліку, яка здійснюється на рівні центрів відповідальності } \\
\text { накопичення інформацації про витрати і доходи, калькулюванні витрат, } \\
\text { визначенні фрінансового результату, підготовки звітності та сприяє аналізу } \\
\text { та оцінці діяльності центрів та підприємства в цілому. }\end{array}$ \\
\hline $\begin{array}{c}\text { О.Я.Чернін } \\
{[13, \text { с. 101-108] }}\end{array}$ & $\begin{array}{l}\text { Система обліку, яка забезпечує відображення, накопичення, аналіз та } \\
\text { надання інформації про витрати і результати, що дозволяє оцінювати } \\
\text { діяльність окремих центрів відповідальності і їх керівників. }\end{array}$ \\
\hline
\end{tabular}

- кожен центр відповідальності має свого керівника (менеджера), відповідального за виконання необхідних завдань;

- кожен центр відповідальності розробляє свої показники для оцінки; чітко фрормуються обов'язки відповідальних за центрами осіб;

- кожен центр відповідальності розробляє і встановлює свої фрорми внутрішньої звітності [4, c. 10-12].

Організація обліку за центрами відповідальності неможлива без виділення окремих видів центрів відповідальності. Аналіз широкого кола наукових джерел засвідчив, що існує досить багато критеріїв, відповідно до яких здійснюється класифікація центрів відповідальності.

Найбільш часто зустрічається критерій (ознака) - «залежність від сорери впливу, рівня повноважень та обов'язків», відповідно до якого центри відповідальності поділяються на: центр доходів, центр витрат, центр прибутку та центр інвестицій [14], Так, центрами витрат є виробничі підрозділи, керівники яких відповідають за величину понесених витрат. В свою чергу, центрами доходів $€$ стуркутрні підрозділи, керівники яких відповідають за розмір сгенерованих доходів. Найбільше значення для багатьох підприємств при організації управлінського обліку грають центри прибутку, керівники яких несуть відповідальність за фрінансові результати. Також в окремих випадках підприємства активно займаються інвестиційною діяльністю, що вимагає фрормування також і центрів інвестицій, керівники яких несуть відповідальність за фрінансові результати та використання прибутку на інвестиційні потреби.

У табл. 3 здійснено порівняльну характеристику центрів відповідальності затрат, доходів, прибутку та інвестицій за такими параметрами, як: завдання управлінського обліку, критерії оцінки діяльності центру, фрінансова відповідальність, повноваження керівників.

Крім наведених вище найбільш поширених центрів відповідальності, що виділяються відповідно до критерію «залежність від сорери впливу, рівня повноважень та обов'язків», існують також і інші критерії.

Так, М.О. Столярова здійснює розподіл центрів відповідальності на підприємстві в залежності від виконуваних фрункцій на наступні центри: центр постачання, центр збуту, центр виробництва, центр надання послуг основному виробництву, центр управління діяльністю, тощо [15, с. 17-22].

По відношенню до основної операційної діяльності підприємства центри відповідальності поділяються на центр основного виробництва та центр допоміжного виробництва [8, c. 174-178].

За ознакою відношення до внутрішнього господарського механізму центри відповідальності поділяються на аналітичні та госпрозрахункові центри [16, с. 69-77]. Ще одним варіантом класифрікації центрів відповідальності є їх поділ за принципами: 1) срункціональний; 2) територіальний; 3) відповідності організаційній структурі; 4) подібності структури витрат [10].

Д. Костроміна здійснює розподіл центрів відповідальності в залежності [17]:

- від визначення мети внутрішньо фрірмового управління виділяє стратегічні та оперативні центри відповідальності;

- від рівня управління - підприємство; відділи та служби підприємства; окремі види виробництва; цех; виробнича ділянка; бригада.

Ґрунтуючись на проведеному аналізі підходів до класифрікації центрів відповідальності під час організації обліку за центрами відповідальності, слід зробити висновок про те, що 
Таблиця 3

Порівняльна характеристика центрів затрат, доходів, прибутку та інвестицій

\begin{tabular}{|c|c|c|c|c|}
\hline \multirow[b]{2}{*}{ Критерій } & \multicolumn{4}{|c|}{ Тип центру відповідальності } \\
\hline & Центр затрат & Центр доходів & Центр прибутку & $\begin{array}{c}\text { Центр } \\
\text { інвестицій }\end{array}$ \\
\hline $\begin{array}{l}\text { Завдання } \\
\text { управлінського } \\
\text { обліку }\end{array}$ & $\begin{array}{l}\text { Вимірювання } \\
\text { і фріксація витрат } \\
\text { на вході в ЦВ }\end{array}$ & \begin{tabular}{|l} 
Фіксація \\
результатів \\
діяльності ЦВ \\
на виході
\end{tabular} & $\begin{array}{l}\text { Вимірювання } \\
\text { і фріксація } \\
\text { витрат на вході } \\
\text { в ЦВ, витрат } \\
\text { усередині цього } \\
\text { центру, кінцевих } \\
\text { результатів його } \\
\text { діяльності } \\
\text { на виході }\end{array}$ & $\begin{array}{l}\text { Вимірювання } \\
\text { і контроль витрат } \\
\text { і доходів ЦВ, } \\
\text { а також оцінка } \\
\text { едективності } \\
\text { використання } \\
\text { інвестицій }\end{array}$ \\
\hline $\begin{array}{l}\text { Критерії оцінки } \\
\text { діяльності } \\
\text { центрів }\end{array}$ & Прямі витрати & Розмір виручки & $\begin{array}{l}\text { Розмір } \\
\text { отриманого } \\
\text { прибутку }\end{array}$ & $\begin{array}{l}\text { Ефективність } \\
\text { використання } \\
\text { інвестицій (норма } \\
\text { прибутку на } \\
\text { інвестиції) }\end{array}$ \\
\hline $\begin{array}{l}\text { Критерії } \\
\text { фінансової } \\
\text { відповідальності } \\
\text { керівників } \\
\text { центрів }\end{array}$ & $\begin{array}{l}\text { Керівник ЦВ } \\
\text { відповідає за } \\
\text { понесені витрати }\end{array}$ & $\begin{array}{l}\text { Керівник } \\
\text { відповідає за } \\
\text { отримання } \\
\text { доходів, } \\
\text { але не несе } \\
\text { відповідальності } \\
\text { за витрати }\end{array}$ & $\begin{array}{l}\text { Керівник } \\
\text { відповідає } \\
\text { одночасно як за } \\
\text { доходи, так і за } \\
\text { витрати Цв }\end{array}$ & $\begin{array}{l}\text { Керівник } \\
\text { відповідає за } \\
\text { доходи і витрати } \\
\text { ЦВ, а також } \\
\text { за ефективність } \\
\text { використання } \\
\text { інвестованих } \\
\text { в нього коштів }\end{array}$ \\
\hline $\begin{array}{l}\text { Управлінські } \\
\text { повноваження } \\
\text { керівників } \\
\text { центрів }\end{array}$ & $\begin{array}{l}\text { Найменші } \\
\text { управлінські } \\
\text { повноваження, } \\
\text { які обмежуються } \\
\text { контролем за } \\
\text { формуванням } \\
\text { витрат і їх } \\
\text { доцільністю } \\
\end{array}$ & $\begin{array}{l}\text { Управлінські } \\
\text { повноваження } \\
\text { зосереджуються } \\
\text { на питаннях } \\
\text { отримання } \\
\text { доходів }\end{array}$ & \begin{tabular}{|l} 
Великі \\
повноваження у \\
прийнятті рішень \\
(наприклад, за \\
кількістю і якістю \\
виробленої \\
продукції, \\
наданих послуг) \\
\end{tabular} & $\begin{array}{l}\text { Найбільші } \\
\text { управлінські } \\
\text { повноваження } \\
\text { (наприклад, } \\
\text { прийняття } \\
\text { власних } \\
\text { інвестиційних } \\
\text { рішень) }\end{array}$ \\
\hline Примітка & $\begin{array}{l}\text { Центри витрат } \\
\text { можуть бути } \\
\text { відокремленими } \\
\text { або входити до } \\
\text { складу інших ЦВ }\end{array}$ & \begin{tabular}{|l|} 
Можуть бути \\
виділені центри \\
маржинального \\
доходу (різниця \\
між виручкою \\
і змінними \\
витратами)
\end{tabular} & $\begin{array}{l}\text { Кількість центрів } \\
\text { прибутку } \\
\text { залежить } \\
\text { від ступеня } \\
\text { децентралізації } \\
\text { управління }\end{array}$ & $\begin{array}{l}\text { Як правило, } \\
\text { центр інвестицій - } \\
\text { це організація } \\
\text { в цілому }\end{array}$ \\
\hline
\end{tabular}

Примітка: ЦВ - центр відповідальності

Джерело: складено авторами на основі [3; 8; 10; 14]

найбільш універсальною класифрікацією варто вважати виділення їх виходячи з обсягу повноважень і відповідальності, критерієм яких є характер економічних показників, за які несе відповідальність відповідний центр доходів, витрат, прибутку або інвестицій, вважаючи цей підхід до класифрікації інваріантним до сфери, галузі та масштабом бізнесу підприємства.

Таким чином, варто зазначити, що облік за центрами відповідальності представляє собою упорядковану систему, яка допомагає вимірювати (оцінювати) відповідність срактично витрачених ресурсів чи досягнутих результатів запланованим показникам по кож- ному підрозділу, що виступає відповідним центром доходів, витрат, прибутку чи інвестицій. Завдяки наявному делегуванню повноважень підрозділу, що визнаний як центр відповідальності, саме завдяки цьому він і отримує подібний статус. При цьому виявлені відхилення по запланованих показниках фріксуються не тільки в тому місці, де вони виникли, але також і по відповідальній особі, що є керівником відповідного центру відповідальності.

Висновки. Узагальнюючи викладене вище, можна зробити наступні висновки. Запровадження центрів відповідальності $\epsilon$ відповіддю на виклики динамічного зовніш- 
нього середовища, коли підприємствам для еорективного управління стає недостатнім простого ведення обліку, а напрямом його вдосконалення стало запровадження центрів відповідальності. Центри відповідальності дають змогу отримувати релевантну інфрормацію про доходи, витрати, фінансові результати з відповідною деталізації по підрозділах підприємства. При цьому виникають нові внутрішньорганізаційні відносини, підрозділи не тільки реалізують спільну стратегію організації, але і безпосередньо беруть участь у їі формуванні, посилюючи її об'єктивність.

Використання центрів відповідальності в загальній структурі підприємства дозволяє розмежувати основні фрункції, повноваження, права та обов'язки, необхідні для здійснення фрінансово-господарської діяльності. Підрозділи в даній ситуації є самостійними одиницями бюджетного (планового, госпрозрахункового) процесу, керівники яких відповідають за виконання бюджетних (планових) показників. Внаслідок делегування повноважень від центрів відповідальності нижчого рівня до вищих можливо визначити відхилення фрактичних результатів діяльності підрозділів та підприємства в цілому за видами продукції (робіт, послуг), місцями виникнення доходів, витрат і відповідальним за ці результати особам (підрозділам).

\section{СПИСОК ВИКОРИСТАНИХ ДЖЕРЕЛ:}

1. Бутинць Ф.Ф. Бухгалтерський управлінський облік : підручник для студентів спеціальності «Облік і аудит» вищих навчальних закладів. 4-тє вид., доп. і перероб. Житомир : ПП «Рута», 2010. 480 с.

2. Лень В.С. Управлінський облік : навч. посіб. 2-е вид., випр. Київ : Знання-Прес, 2016. 317 с.

3. Миронюк О.В. Облік витрат за центрами виникнення і сферами відповідальності - основа контролю за витратами. Збірник наукових праць Буковинського університету. Серія : Економічні науки. 2019. Вип. 5. URL: http://zbirnuk.bukuniver.edu.ua/issue_articles/13.pdf

4. Атамас П.Н. Управлінський облік : навч. посіб. М-во освіти і науки України, Дніпропетров. Ун-т економіки та права. 2-ге вид. Київ : ЦУЛ, 2009. 440 с.

5. Добровський В.М., Гнилицька Л.В., Коршикова Р.С. Управлінський облік : навчальний посібник. 3-ге вид., зі змінами. КНЕУ, 2012. 235 с.

6. Дюкарєва Х.Л. Концептуальні основи побудови облікової системи центрів відповідальності суб'єктів господарювання. Науковий вісник НЛтУ України. 2016. № 18.6. С. 159-168.

7. Жукова І.Г. Сучасне поняття центрів відповідальності в системі управління витратами. Економічні науки. Сер. : Облік і фрінанси. 2012. Вип. 9(1). С. 393-398.

8. Лепетан I.М. Організація управлінського обліку за центрами витрат у сільськогосподарських підприємствах. Агросвіт. 2019. № 3. С. 19-24.

9. Сидоренко Р.В. Внутрішня звітність центрів відповідальності. Вісник Львівської комерційної академії. 2011. Вип. 35. С. 326-328.

10. Скрипник М.І. Організація обліку витрат у розрізі центрів витрат та центрів. Облік і фінанси АПК. 2017. № 1. С. 46-49.

11. Миронова Ю.Ю. Облік витрат за «центрами відповідальності» та «центрами витрат» на підприємстві. Науковий вісник Ужгородського університету. Серія : Економіка. Ужгород : УжНУ, 2016. № 29.4 .1$. C. $174-178$.

12. Полікарпова О.С. Особливості впровадження управлінського обліку на основі «центрів відповідальності». Вісник Житомирського державного технологічного університету. Серія : Економічні науки. 2013. № 4. С. $97-100$.

13. Чернін О.Я. Управлінський облік за центрами відповідальності на підприємствах оптової торгівлі. Вісник Житомирського державного технологічного університету. Серія : Економічні науки. 2014. № 3. С. $101-108$.

14. Берестецька О. Застосування концепції центрів відповідальності для управління витратами підприємства. Вісник Тернопільського національного технічного універсuтеmy. 2018. № 11(43). URL: http://elartu.tntu.edu.ua/ bitstream/123456789/17918/5/Berestetska_stattya.pdf

15. Столярова, М. А. Центры ответственности: сущность и необходимость создания. Экономический анализ: теория и практика. 2017. № 16(97). С. 17-22.

16. Лищенко О.Г., Горбань В.В. Облік витрат за центрами відповідальності. Вісник Запорізького національного університету. Економічні науки. 2018. № 3. С. 69-77.

17. Костромина Д.В. Управление затратами и прибылью предприятия на основе организации центров фринансовой ответственности. 2014. URL: http://www.diplom.krsk.info/stFsost_22.htm 


\section{REFERENCES:}

1. Butyncj F.F. (2010) Bukhghaltersjkyj upravlinsjkyj oblik: pidruchnyk dlja studentiv specialjnosti «Oblik i audyt» vyshhykh navchaljnykh zakladiv. 4-tje vyd., dop. i pererob. Zhytomyr: PP «Ruta», 480 p.

2. Lenj V.S. (2016) Upravlinsjkyj oblik: navch. posib. 2-e vyd., vypr. Kyiv: Znannja-Pres, 317 p.

3. Myronjuk O.V. (2019) Oblik vytrat za centramy vynyknennja i sferamy vidpovidaljnosti - osnova kontrolju za vytratamy. Zbirnyk naukovykh pracj Bukovynsjkogho universytetu. Serija: Ekonomichni nauky, vol. 5. URL: http://zbirnuk.bukuniver.edu.ua/issue_articles/13.pdf

4. Atamas P.N. (2009) Upravlinsjkyj oblik: navch. posib. M-vo osvity i nauky Ukrajiny, Dnipropetrov. Un-t ekonomiky ta prava. 2-ghe vyd. Kyiv: CUL, 440 p.

5. Dobrovsjkyj V.M., Ghnylycjka L.V., Korshykova R.S. (2012) Upravlinsjkyj oblik: navchaljnyj posibnyk. 3-ghe vyd., zi zminamy. KNEU, $235 \mathrm{p}$.

6. Djukarjeva Kh.L. (2016) Konceptualjni osnovy pobudovy oblikovoji systemy centriv vidpovidaljnosti sub'jektiv ghospodarjuvannja. Naukovyj visnyk NLTU Ukrajiny, no. 18.6, pp. 159-168.

7. Zhukova I.Gh. (2012) Suchasne ponjattja centriv vidpovidaljnosti v systemi upravlinnja vytratamy. Ekonomichni nauky. Cer.: Oblik i finansy, vol. 9(1), pp. 393-398.

8. Lepetan I.M. (2019) Orghanizacija upravlinsjkogho obliku za centramy vytrat u siljsjkoghospodarsjkykh pidpryjemstvakh. Aghrosvit, no. 3, pp. 19-24.

9. Sydorenko R.V. (2011) Vnutrishnja zvitnistj centriv vidpovidaljnosti. Visnyk Ljvivsjkoji komercijnoji akademiji, vol. 35, pp. 326-328.

10. Skrypnyk M.I. (2017) Orghanizacija obliku vytrat u rozrizi centriv vytrat ta centriv. Oblik i finansy APK, no. 1, pp. $46-49$.

11. Myronova Ju.Ju. (2016) Oblik vytrat za «centramy vidpovidaljnosti» ta «centramy vytrat» na pidpryjemstvi. Naukovyj visnyk Uzhghorodsjkogho universytetu. Serija: Ekonomika. Uzhghorod: UzhNU, no. 29, ch. 1, pp. 174-178.

12. Polikarpova O. S. (2013) Osoblyvosti vprovadzhennja upravlinsjkogho obliku na osnovi «centriv vidpovidaljnosti». Visnyk Zhytomyrsjkogho derzhavnogho tekhnologhichnogho universytetu. Serija: Ekonomichni nauky, no. 4, pp. 97-100.

13. Chernin O. Ja. (2014) Upravlinsjkyj oblik za centramy vidpovidaljnosti na pidpryjemstvakh optovoji torghivli. Visnyk Zhytomyrsjkogho derzhavnogho tekhnologhichnogho universytetu. Serija: Ekonomichni nauky, no. 3, pp. 101-108.

14. Berestecjka O. (2018) Zastosuvannja koncepciji centriv vidpovidaljnosti dlja upravlinnja vytratamy pidpryjemstva. Visnyk Ternopiljsjkogho nacionaljnogho tekhnichnogho universytetu, no. 11(43). URL: http://elartu.tntu.edu.ua/ bitstream/123456789/17918/5/Berestetska_stattya.pdf

15. Stoljarova, M.A. (2017) Centry otvetstvennosty: sushhnostj y neobkhodymostj sozdanyja. Ekonomycheskyj analyz: teoryja y praktyka, no. 16(97), pp. 17-22.

16. Lyshhenko O.Gh., Ghorbanj V.V. (2018) Oblik vytrat za centramy vidpovidaljnosti. Visnyk Zaporizjkogho nacionaljnogho universytetu. Ekonomichni nauky, no. 3, pp. 69-77.

17. Kostromyna D.V. (2014) Upravlenye zatratamy y prybyljju predpryjatyja na osnove orghanyzacyy centrov fynansovoj otvetstvennosty. URL: http://www.diplom.krsk.info/stFsost_22.htm 